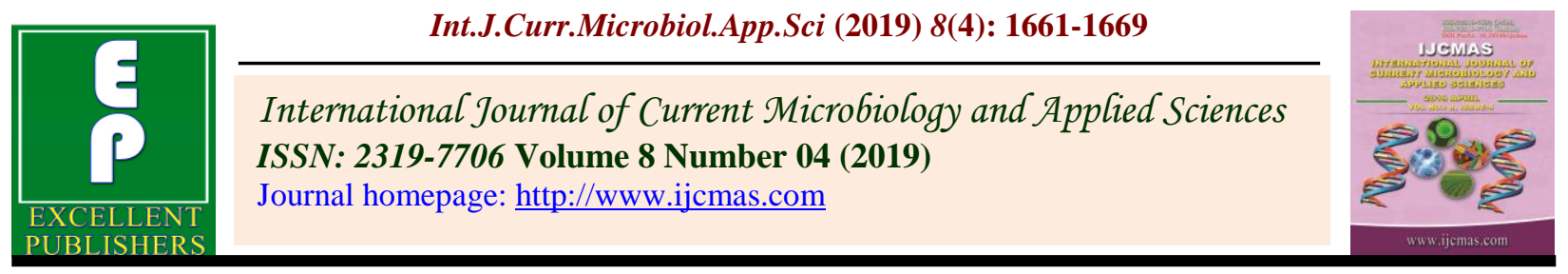

Original Research Article

https://doi.org/10.20546/ijcmas.2019.804.194

\title{
Assessment of Variability in Half Sib Progenies of Grewia optiva Drummond for Various Qualitative and Quantitative Traits in North Western Himalayas
}

\author{
Shikha Bhagta $^{1 *}$, H.P. Sankhyan ${ }^{1}$, J.P. Sharma ${ }^{1}$ and Reena Kumari ${ }^{2}$ \\ ${ }^{1}$ Department of Tree Improvement and Genetic Resources, Dr YS Parmar University of \\ Horticulture and Forestry, Nauni-173 230, Solan, HP, India \\ ${ }^{2}$ Department of Vegetable Science, Dr YS Parmar University of Horticulture and Forestry, \\ Nauni-173 230, Solan, HP, India \\ *Corresponding author
}

\section{A B S T R A C T}

\section{Keywords}

Half sib families, Grewia optiva Drummond, morphometric, Fodder quality traits

Article Info

Accepted:

12 March 2019

Available Online:

10 April 2019
To assess the mean performance and extent of genetic variability, 40 half sib progenies of Grewia optiva Drummnond were evaluated in randomized complete block design with three replications. The observations were recorded on various morphometeric and fodder quality parameters. The analysis of variance indicated highly significant differences among the various half sib families for all the traits studied. The experimental results revealed that out of 40 families ten families viz. SI-15, SO-3, HA-2, HA-3, HA-4, SO-7, SH-7, SO-4, SI-6 and SI-14 were found superior on the basis of overall mean performance for all quantitative and qualitative traits under study. Hence, these half sib families can be used in further breeding programme.

\section{Introduction}

Livestock plays an important role in mountain farming systems and Himachal Pradesh is one of the important livestock rearing states in India. In this state, mixed agricultural production system is practiced by the farmers with both crop and livestock husbandry as the important components. Availability of nutritious fodder is the biggest constraint in animal husbandry in this state. Except for rainy season (July to September), there is scarcity of fodder throughout the year. In hilly and mountain regions, the demand of feeds and fodder for livestock is much higher than their availability (Singh and Bimal, 2004). Grewia optiva is one of the most important tree species used as fodder in Himachal Pradesh (Singh, 2005). It belongs to family Tiliaceae and naturally distributed in India, Bhutan, Nepal, and Pakistan. In India it is distributed in areas of Himachal Pradesh, Jammu and Kashmir, Punjab, Sikkim and Uttar Pradesh (Hooker, 1875). Several species of Grewia are used as a very important multipurpose or agro forestry tree, of 
which Grewia optiva, commonly known as 'Beul', having chromosome number $2 \mathrm{n}=18$ (Coleman, 1982) and very popular agroforestry tree which is grown in low and mid-hills regions in the western and central Himalaya on account of its utility as fodder, fuel and fibre. Flowers appear with the new flush of leave and it flowers from the end of March to June; flowers are monoecious and lemon yellow in color. Greater the diversity in material, more the chances of getting the desired types. This variation, can be utilized for breeding purposes for some useful traits like fodder value, growth rate and for conservation of species. With the increase in demand for fodder, there is a need to develop clones of genetically superior trees. Therefore, it is essential to understand the genetic architecture of Grewia optiva, which provides useful guidelines to determine the source population and from which it is possible to derive appropriate genotypes with desired characters. The study of variability for various characters is pre-requisite for a plant breeder to develop a high yielding variety with good quality. Therefore, evaluating locally adopted beul families for commercial cultivation is priority area of research in improving the fodder quality.

\section{Materials and Methods}

Present investigation has been carried out in the Experimental Research Farm of the Department of Tree Improvement and Genetic Resources, College of Forestry, Dr YS Parmar University of Horticulture and Forestry, Nauni, Solan (Himachal Pradesh). A seedling seed orchard of Grewia optiva Drummond has been established in July 2000, which consists of 60 families each under three replications at spacing of $2 \mathrm{~m} \times 2 \mathrm{~m}$. These different families have been sourced from various districts of Himachal Pradesh which include Sirmour, Solan, Chamba, Bilaspur, Mandi, Hamirpur and Kangra (Table 1). For the present study out of 60 families only 40 families are selected and were evaluated for various morphometric and fodder quality parameters and recorded observations on various morphometric parameters viz. plant height $(\mathrm{m})$, plant diameter $(\mathrm{cm})$, number of leaves, leaf area $\left(\mathrm{cm}^{2}\right)$, leaf fresh weight $(\mathrm{g})$, leaf dry weight $(\mathrm{g})$, leaf dry matter content $(\%)$, fodder yield $(\mathrm{kg})$, total fresh leaf biomass (g) and fodder quality parameters of families viz., ether extract (\%), crude fibre (\%), crude protein $(\%)$, total ash (\%) and nitrogen free extract (\%). Data has been analyzed statistically as per the method suggested by Panse and Sukhatme (1967) and chandel (1984). The table for analysis of variance (ANOVA) was set as explained by Gomez and Gomez (1983).

\section{Results and Discussion}

The analysis of variance indicated highly significant differences among the families for all the morphometric traits and fodder quality traits studied, which revealed the existence of good deal of variability in the seedling seed orchard of Grewia optiva. The mean performance of all the families (Table 2 and 3 ), general mean value, range and coefficient of variance (Table 4 and 5) for various traits under study is described below:

\section{Morphometric traits}

Significant variations were obtained among all the families for plant height (Table 2). Plant height ranged from 4.67 - $9.20 \mathrm{~m}$ (Table 4). General mean for the character was 7.04 m. Family SO-1 show highest plant height and it was found statistically at par with seven other families viz., BI-3, HA-2, SH-2, SI-7, SI-10, SO-1, SO-7 and SO-12. Plant diameter ranged from 9.94- $16.19 \mathrm{~cm}$ with general mean value of $12.16 \mathrm{~cm}$. Family HA-4 recorded maximum diameter and found statically at par with nine families viz., BI-4, CH-4, HA-2, HA-4, SH-2, SI-7, SI-10, SO-1 and SO-12. Family SI-4 showed minimum 
value for diameter. Number of leaves is a major yield contributing trait in Grewia optiva. All the families' studies revealed significant variations for this character. It ranged from 3634.3 - 1687.6. Family with mean value of 2718.95. Maximum number of leaves per plant was observed in family $\mathrm{SH}-3$ and it was statistically at par with 12 other families viz. CH-4, CH-6, HA-2, HA-4, KA3, SH-3, SH-7, SI-4, SI-6, SI-10, SI-15 and SO-7. Minimum number of leaves per plant was observed in BI-1. A perusal of data (Table 2) revealed that the differences in leaf area were significant among the different families. It ranged from 77.22 - 40.84. General mean for the character was 58.25 (Table 4). Family SH-7 recorded the maximum leaf area of while the minimum leaf area was recorded in BI-1. Families $\mathrm{CH}$ 1, HA-3, HA-4, MA-2, SH-7, SI-10, SI-15, SO-3, SO-4, and SO-7 were at par with the maximum. Fresh weight of 100 leaves $(\mathrm{g})$ ranged from 48.16 - 87.00 in families SO-4 and BI-3 respectively. General mean for the character was 64.57.Families $\mathrm{CH}-1$, HA-3, HA-4, MA-2, SH-7, SI-10, SI-15, SO-3, SO-4 and SO-7 were statistically at par with the maximum. Dry weight of 100 leaves (g) ranged from $25.16-50.33(\mathrm{~g})$. General mean of 33.71 was recorded for this character. Maximum dry weight of 100 leaves was recorded in HA-3 and it was found statistically at par with $\mathrm{CH}-1, \mathrm{HA}-3, \mathrm{HA}-4$, MA-2, SH-7, SI-10, SI-15, SO-3, SO-4 and SO-7. Minimum dry weight of 100 leaves is recorded for family BI-3. Appraisal of the data (Table 2) elucidated that SO-8 attained the maximum $(55.56 \%)$ leaf dry matter content. HA-3 showed the lowest leaf dry matter content $(41.22 \%)$. General mean for the character was 48.19 percent (Table 4). Appraisal of the data presented in table 2 elucidated that HA-3 attained the maximum fodder yield $(13.81 \mathrm{~kg})$ followed by $\mathrm{SO}-3$, SO-5, SO-9, S0-4 and SO-7 and SI-15 respectively. Minimum (8.84) was observed for family BI-1. As clearly indicated in Table 2, total fresh leaf biomass ( $g$ ) exhibited significant differences among families. Maximum total fresh leaf biomass was observed in family SH-7 (3024.97g), whereas the minimum was recorded in family BI-1 (893.36g). Family SI-15 and SO-7 found statically at par with maximum. General mean was $1770.81 \mathrm{~g}$ for the character. Wide range of variation for different morphometric traits recorded by Sehgal and Jaswal (1996) Rathore (1997) in Grewia optiva, Bhat (1999) in Albizia lebbek and Choudhary (2000) in Toona ciliata, Pant et al., (2003) in Grewia optiva; Wani et al., (2009) in Bauhinia variegata and Sankhyan et al., (2009) in Grewia laevigata. Similar variations were reported with respect to leaf dimensions and leaf area by Wani et al., (2009) in Bauhinia variegata, Sankhyan et al., (2009) in Grewia laevigata, Bhat (2010) in Grewia optiva, Bhagta (2015) in Grewia optiva and Sankhyan et al., (2016) in Grewia optiva lend support to the present findings.

\section{Fodder quality traits}

Crude protein is one of the most important constituents of fodder quality particularly for the growing demand of meat producing animals, as it contains the muscle building fraction of the diet. It is generally used as an index of nutritive value. Among 40 families crude protein ranged from 18.09 -22.11 per cent (Table 5). The maximum of crude protein $(22.10 \%)$ was observed in family HA-2 and the minimum in family MA-2 (Table 3) followed by family $\mathrm{CH}-3$, HA-2, SI11, SI-14, SI-16, SO-3, SO-8, SO-9 and SO10. The crude fibre was observed in family HA-2 $(21.84 \%)$ whereas the minimum was recorded in family SI-11 (18.58\%). Thirteen families viz. CH-1, CH-3, HA-2, HA-4, SH-7, SI-3, SI-7, SI-14, SI-15, SO-1, SO-4, SO-7 and SO-10 found statically at par with maximum. General mean was 20.52 for crude 
fibre (Table 5). Highest value of ether extract content was recorded for family MA-3 (5.88 $\%)$ which was closely followed by $\mathrm{CH}-1, \mathrm{CH}-$ 3, CH-6, HA-3, KA-3MA-3, SI-15, SI-16, SO-1, SO-2, SO-3 and SO-7. However, lowest value was recorded for family $\mathrm{SH}-3$ $(8.80 \%)$. General mean was 5.34 for the character. Total ash ranged from $13.13-10.7$ percent. General mean for this trait was 11.96 . Eighteen families recorded higher total ash content than population mean. Maximum $(13.13 \%)$ total ash content was recorded in family S0-12, and was statistically at par with families CH-1, HA-2, SI-11, SI-14, SI-16 and SO-12. Significant differences were observed with respect to nitrogen free extract (\%) in all the families studied. It ranged from 38.3744.25 per cent. General mean for the character was 41.18. Maximum nitrogen free extract (44.25\%) was observed in family HA-3 whereas minimum $(38.37 \%)$ was noticed in family $\mathrm{SH}-7$. Presence of tremendous genetic variation was also reported by Kaushal (1978) in proximate principles and mineral nutrients in Grewia optiva; Rathore (1997) in Grewia optiva; Gera et al., (2002) in Dalbergia sisso; Wani et al., (2009) in Bauhinia variegata and Sankhyan et al., (2009) in Grewia laevigata, Bhat (2010), Bhagta (2015) and Sankhyan et al., (2016) in Grewia optiva lend support to the present findings.

Table.1 Families selected in established open pollinated seedling seed orchard of Grewia optiva

\begin{tabular}{|l|l|l|l|l|l|l|l|}
\hline Sr. No. & District & Family & Code & Sr. No & District & Family & Code \\
\hline $\mathbf{1}$ & Bilaspur & Bilaspur & UHF- BI-1 & 21 & Sirmour & Dilman & UHF -SI-4 \\
\hline $\mathbf{2}$ & Bilaspur & Auhar & UHF- BI-3 & 22 & Sirmour & Deyoltikkeri & UHF SI-5 \\
\hline $\mathbf{3}$ & Bilaspur & Kuthira & UHF -BI-4 & 23 & Sirmour & Kalaghat & UHF -SI-6 \\
\hline $\mathbf{4}$ & Chamba & Chanad & UHF -CH-1 & 24 & Sirmour & Nandel & UHF -SI-7 \\
\hline $\mathbf{5}$ & Chamba & Balu & UHF -CH-3 & 25 & Sirmour & Seenaghat & UHF -SI-10 \\
\hline $\mathbf{6}$ & Chamba & Audhpur & UHF -CH-4 & 26 & Sirmour & Adgu & UHF -SI-11 \\
\hline $\mathbf{7}$ & Chamba & Saru & UHF -CH-6 & 27 & Sirmour & Sarpadol & UHF -SI-13 \\
\hline $\mathbf{8}$ & Hamirpur & Patta Balakhar & UHF -HA-2 & 28 & Sirmour & Saraha Chakli & UHF -SI-14 \\
\hline $\mathbf{9}$ & Hamirpur & Bassi & UHF -HA-3 & 29 & Sirmour & Madhobag & UHF -SI-15 \\
\hline $\mathbf{1 0}$ & Hamirpur & Hamirpur & UHF -HA-4 & 30 & Sirmour & Nainatikker & UHF -SI-16 \\
\hline $\mathbf{1 1}$ & Hamirpur & Ghahar & UHF -HA-5 & 31 & Solan & Gaura & UHF -SO-1 \\
\hline $\mathbf{1 2}$ & Kangra & Dharamshala & UHF -KA-1 & 32 & Solan & Nauni & UHF -SO-2 \\
\hline $\mathbf{1 3}$ & Kangra & Bhalun & UHF -KA-2 & 33 & Solan & Dharja & UHF -SO-3 \\
\hline $\mathbf{1 4}$ & Kangra & Varal & UHF -KA-3 & 34 & Solan & Deog & UHF -SO-4 \\
\hline $\mathbf{1 5}$ & Mandi & Bachhwan & UHF -MA-2 & 35 & Solan & Badhlech & UHF -SO-5 \\
\hline $\mathbf{1 6}$ & Mandi & Bambla & UHF -MA-3 & 36 & Solan & Oyali & UHF -SO-7 \\
\hline $\mathbf{1 7}$ & Shimla & Ninmun & UHF -SH-2 & 37 & Solan & Kailar & UHF -SO-8 \\
\hline $\mathbf{1 8}$ & Shimla & Jeury & UHF -SH-3 & 38 & Solan & Deothi & UHF -SO-9 \\
\hline $\mathbf{1 9}$ & Shimla & Taradevi & UHF -SH-7 & 39 & Solan & Jaunaji & UHF -SO-10 \\
\hline $\mathbf{2 0}$ & Sirmour & Deothal & UHF -SI-3 & 40 & Solan & Kasholi & UHF -SO-12 \\
\hline
\end{tabular}


Table.2 Variation in mean performance for morphometric traits among different families of Grewia optiva

\begin{tabular}{|c|c|c|c|c|c|c|c|c|c|c|}
\hline $\begin{array}{l}\text { Sr. } \\
\text { No. }\end{array}$ & Family & $\begin{array}{l}\text { Height } \\
\text { (m) }\end{array}$ & $\begin{array}{l}\text { Diameter } \\
(\mathbf{c m})\end{array}$ & $\begin{array}{l}\text { Leaf } \\
\text { area } \\
\left(\mathrm{cm}^{2}\right)\end{array}$ & $\begin{array}{c}\text { Estimated } \\
\text { number of } \\
\text { leaves }\end{array}$ & $\begin{array}{l}\text { Fresh } \\
\text { weight of } \\
100 \text { leaves } \\
\text { (g) }\end{array}$ & $\begin{array}{c}\text { Dry weight } \\
\text { of } 100 \\
\text { leaves }(g)\end{array}$ & $\begin{array}{l}\text { Leaf dry } \\
\text { matter } \\
\text { content } \\
(\%)\end{array}$ & $\begin{array}{l}\text { Fodder yield } \\
\qquad(\mathrm{Kg})\end{array}$ & $\begin{array}{c}\text { Total fresh } \\
\text { leaf } \\
\text { biomass (g) }\end{array}$ \\
\hline 1 & BI -1 & 7.00 & 11.57 & 40.84 & 1687.6 & 52.90 & 27.33 & 48.38 & 8.84 & 893.36 \\
\hline 2 & BI-3 & 8.00 & 11.38 & 52.44 & 2231.0 & 48.16 & 25.16 & 47.10 & 10.29 & 1074.60 \\
\hline 3 & BI-4 & 6.33 & 13.90 & 48.43 & 1989.3 & 49.07 & 25.33 & 48.24 & 10.33 & 976.10 \\
\hline 4 & CH-1 & 5.76 & 11.31 & 68.85 & 2267.7 & 76.50 & 43.83 & 42.69 & 10.49 & 1734.77 \\
\hline 5 & $\mathrm{CH}-3$ & 7.46 & 12.01 & 56.92 & 2660.7 & 65.33 & 36.67 & 43.83 & 11.85 & 1738.30 \\
\hline 6 & $\mathrm{CH}-4$ & 7.17 & 14.28 & 45.29 & 3351.7 & 52.84 & 27.67 & 47.61 & 9.58 & 1771.02 \\
\hline 7 & CH-6 & 6.33 & 10.22 & 63.57 & 3016.3 & 59.02 & 28.67 & 51.37 & 9.61 & 1780.24 \\
\hline 8 & HA-2 & 9.10 & 14.39 & 65.89 & 3050.7 & 73.47 & 27.50 & 50.68 & 9.98 & 1698.20 \\
\hline 9 & HA-3 & 7.00 & 11.47 & 75.30 & 2738.3 & 86.17 & 50.33 & 41.22 & 13.81 & 2359.53 \\
\hline 10 & HA-4 & 7.50 & 16.19 & 73.85 & 3123.0 & 77.17 & 43.17 & 43.88 & 12.42 & 2409.92 \\
\hline 11 & HA-5 & 6.50 & 10.32 & 48.57 & 2332.0 & 53.17 & 27.17 & 48.60 & 8.99 & 1239.85 \\
\hline 12 & KA-1 & 6.67 & 11.00 & 53.51 & 2559.3 & 62.43 & 32.17 & 47.90 & 10.27 & 1597.88 \\
\hline 13 & KA-2 & 6.83 & 11.34 & 57.93 & 2514.7 & 64.33 & 31.67 & 50.71 & 10.27 & 1617.77 \\
\hline 14 & KA-3 & 6.67 & 11.85 & 56.33 & 3187.7 & 61.33 & 30.83 & 49.60 & 9.94 & 1955.10 \\
\hline 15 & MA-2 & 6.67 & 11.82 & 66.20 & 2721.7 & 72.17 & 38.83 & 46.98 & 11.40 & 1964.14 \\
\hline 16 & MA-3 & 6.00 & 10.51 & 55.54 & 2807.3 & 62.50 & 33.83 & 46.76 & 10.81 & 1754.58 \\
\hline 17 & $\mathrm{SH}-2$ & 7.53 & 14.79 & 59.12 & 2423.3 & 56.33 & 27.17 & 51.44 & 9.69 & 1365.14 \\
\hline 18 & SH-3 & 7.50 & 11.50 & 55.61 & 3634.3 & 70.00 & 39.83 & 42.86 & 11.66 & 2544.03 \\
\hline 19 & SH-7 & 7.50 & 11.53 & 77.22 & 3521.0 & 86.17 & 48.50 & 43.84 & 13.10 & 3024.97 \\
\hline
\end{tabular}




\begin{tabular}{|c|c|c|c|c|c|c|c|c|c|c|}
\hline 20 & SI-3 & 7.17 & 10.91 & 48.93 & 2366.0 & 54.50 & 26.83 & 50.83 & 10.05 & 1289.47 \\
\hline 21 & SI-4 & 5.84 & 9.94 & 51.97 & 2920.7 & 61.17 & 30.17 & 50.31 & 10.75 & 1786.47 \\
\hline 22 & SI-5 & 4.67 & 10.60 & 60.89 & 2760.0 & 61.50 & 28.83 & 53.19 & 10.36 & 1697.40 \\
\hline 23 & SI-6 & 7.17 & 11.45 & 58.95 & 3320.3 & 70.83 & 32.83 & 53.71 & 11.39 & 2351.90 \\
\hline 24 & SI-7 & 8.67 & 13.78 & 62.87 & 2793.0 & 71.50 & 39.00 & 46.02 & 12.35 & 1997.00 \\
\hline 25 & SI-10 & 8.63 & 13.87 & 65.29 & 2902.0 & 78.17 & 42.67 & 45.81 & 13.32 & 2268.40 \\
\hline 26 & SI-11 & 7.00 & 11.61 & 53.93 & 2470.3 & 59.33 & 32.50 & 45.00 & 10.87 & 1465.73 \\
\hline 27 & SI-13 & 7.50 & 12.24 & 59.88 & 2092.7 & 65.83 & 34.83 & 47.08 & 11.60 & 1377.67 \\
\hline 28 & SI-14 & 7.50 & 12.95 & 62.96 & 2509.7 & 68.33 & 34.67 & 49.17 & 12.46 & 1714.94 \\
\hline 29 & SI-15 & 7.17 & 12.40 & 66.00 & 3623.7 & 73.77 & 39.67 & 46.38 & 13.39 & 2673.06 \\
\hline 30 & SI-16 & 6.83 & 11.80 & 47.19 & 2810.3 & 49.00 & 25.50 & 47.76 & 9.41 & 1377.06 \\
\hline 31 & SO-1 & 9.20 & 13.45 & 49.51 & 3094.0 & 54.40 & 28.67 & 46.88 & 11.19 & 1683.14 \\
\hline 32 & SO-2 & 7.17 & 11.66 & 48.55 & 2535.3 & 64.10 & 31.67 & 50.60 & 11.11 & 1625.15 \\
\hline 33 & SO-3 & 6.17 & 12.49 & 66.35 & 2426.7 & 77.33 & 41.33 & 47.01 & 13.74 & 1876.62 \\
\hline 34 & $\mathrm{SO}-4$ & 6.67 & 11.31 & 75.93 & 2392.0 & 87.00 & 46.00 & 47.46 & 13.45 & 2081.04 \\
\hline 35 & SO-5 & 6.00 & 10.35 & 50.22 & 2808.3 & 56.53 & 26.17 & 53.73 & 13.74 & 1587.64 \\
\hline 36 & SO-7 & 7.83 & 12.80 & 69.23 & 3402.3 & 77.43 & 41.83 & 46.50 & 13.45 & 2634.54 \\
\hline 37 & SO-8 & 6.50 & 12.87 & 53.79 & 2728.0 & 57.52 & 25.83 & 55.56 & 10.02 & 1569.15 \\
\hline 38 & SO-9 & 6.50 & 12.17 & 56.41 & 2254.0 & 66.05 & 34.83 & 47.60 & 13.50 & 1488.84 \\
\hline 39 & SO-10 & 6.00 & 10.72 & 56.34 & 2309.0 & 62.33 & 31.50 & 50.06 & 9.56 & 1439.28 \\
\hline 40 & SO-12 & 8.17 & 15.75 & 53.78 & 2422.0 & 55.00 & 27.47 & 50.07 & 10.94 & 1332.10 \\
\hline \multicolumn{2}{|c|}{ C.D (0.05) } & 1.67 & 3.10 & 12.14 & 743.98 & 15.30 & 10.27 & 4.95 & 2.40 & 373.46 \\
\hline
\end{tabular}


Table.3 Variation in mean performance for fodder quality parameters among different families of Grewia optiva

\begin{tabular}{|c|c|c|c|c|c|c|}
\hline Sr. No. & $\begin{array}{l}\text { Family } \\
\text { code }\end{array}$ & $\begin{array}{c}\text { Crude protein } \\
(\%)\end{array}$ & $\begin{array}{c}\text { Crude fiber } \\
(\%)\end{array}$ & $\begin{array}{c}\text { Ether extract } \\
(\%)\end{array}$ & Total ash (\%) & $\begin{array}{c}\text { N.F.E } \\
(\%)\end{array}$ \\
\hline 1 & BI -1 & 20.46 & 20.54 & 4.85 & 12.09 & 42.06 \\
\hline 2 & BI-3 & 20.60 & 20.18 & 5.56 & 12.31 & 41.35 \\
\hline 3 & BI-4 & 20.65 & 20.52 & 5.06 & 12.14 & 41.63 \\
\hline 4 & $\mathrm{CH}-1$ & 20.56 & 21.81 & 5.62 & 13.09 & 38.92 \\
\hline 5 & $\mathrm{CH}-3$ & 21.97 & 21.40 & 5.82 & 11.84 & 38.97 \\
\hline 6 & $\mathrm{CH}-4$ & 19.85 & 20.86 & 4.83 & 11.92 & 42.54 \\
\hline 7 & CH-6 & 21.63 & 18.73 & 5.72 & 12.37 & 41.55 \\
\hline 8 & HA-2 & 22.11 & 21.84 & 4.87 & 11.34 & 39.84 \\
\hline 9 & HA-3 & 18.85 & 19.30 & 5.80 & 11.80 & 44.25 \\
\hline 10 & HA-4 & 21.03 & 21.68 & 5.55 & 12.85 & 38.89 \\
\hline 11 & HA-5 & 19.57 & 19.24 & 5.30 & 12.46 & 43.43 \\
\hline 12 & KA-1 & 19.53 & 20.92 & 4.96 & 12.17 & 42.42 \\
\hline 13 & KA-2 & 19.84 & 20.17 & 5.04 & 10.93 & 44.02 \\
\hline 14 & KA-3 & 20.31 & 19.68 & 5.71 & 12.55 & 41.75 \\
\hline 15 & MA-2 & 18.09 & 20.96 & 5.51 & 13.03 & 42.41 \\
\hline 16 & MA-3 & 19.93 & 19.73 & 5.88 & 12.66 & 41.80 \\
\hline 17 & $\mathrm{SH}-2$ & 18.98 & 19.30 & 5.26 & 12.69 & 43.77 \\
\hline 18 & SH-3 & 20.03 & 19.29 & 4.65 & 12.95 & 43.08 \\
\hline 19 & SH-7 & 19.84 & 21.43 & 5.10 & 15.26 & 38.37 \\
\hline 20 & SI-3 & 19.98 & 21.33 & 5.20 & 12.66 & 40.83 \\
\hline 21 & SI-4 & 21.59 & 18.78 & 5.62 & 11.96 & 42.05 \\
\hline 22 & SI-5 & 21.47 & 21.00 & 5.35 & 11.38 & 40.80 \\
\hline 23 & SI-6 & 21.64 & 18.87 & 5.56 & 11.83 & 42.10 \\
\hline 24 & SI-7 & 20.66 & 21.32 & 5.10 & 11.85 & 41.07 \\
\hline 25 & SI-10 & 21.58 & 20.31 & 5.31 & 11.95 & 40.85 \\
\hline 26 & SI-11 & 21.73 & 18.59 & 5.54 & 11.90 & 42.24 \\
\hline 27 & SI-13 & 19.69 & 19.44 & 5.25 & 12.82 & 42.80 \\
\hline 28 & SI-14 & 21.67 & 21.44 & 4.97 & 10.74 & 41.18 \\
\hline 29 & SI-15 & 21.57 & 21.64 & 5.84 & 10.84 & 40.11 \\
\hline 30 & SI-16 & 21.64 & 21.07 & 5.86 & 11.49 & 39.94 \\
\hline 31 & SO-1 & 21.30 & 21.35 & 5.77 & 11.76 & 39.82 \\
\hline 32 & $\mathrm{SO}-2$ & 20.57 & 19.77 & 5.71 & 10.82 & 43.13 \\
\hline 33 & $\mathrm{SO}-3$ & 21.89 & 19.84 & 5.78 & 11.47 & 41.02 \\
\hline 34 & SO-4 & 21.07 & 21.65 & 5.08 & 10.90 & 41.30 \\
\hline 35 & $\mathrm{SO}-5$ & 20.57 & 21.23 & 5.21 & 12.23 & 40.76 \\
\hline 36 & SO-7 & 21.46 & 21.34 & 5.81 & 11.43 & 39.96 \\
\hline 37 & SO-8 & 21.74 & 21.13 & 4.90 & 11.35 & 40.88 \\
\hline 38 & SO-9 & 21.71 & 20.72 & 4.82 & 11.25 & 41.50 \\
\hline 39 & SO-10 & 21.86 & 21.76 & 4.84 & 11.72 & 39.82 \\
\hline 40 & SO-12 & 20.68 & 20.86 & 5.25 & 13.13 & 40.08 \\
\hline C.D(0.05) & & 0.28 & 0.58 & 0.46 & 0.41 & 0.82 \\
\hline
\end{tabular}


Table.4 General mean, range and coefficient of variance (C.V.) of morphometric and leaf parameters among different families of Grewia optiva

\begin{tabular}{|c|l|c|c|c|}
\hline Sr. No. & \multicolumn{1}{|c|}{ Parameter } & Mean & Range & C.V. \\
\hline $\mathbf{1}$ & Height $(\mathrm{m})$ & 7.04 & $4.67-9.20$ & 14.62 \\
\hline $\mathbf{2}$ & Diameter $(\mathrm{cm})$ & 12.16 & $9.94-16.19$ & 12.16 \\
\hline $\mathbf{3}$ & Leaf area $(\mathrm{cm})$ & 58.25 & $40.84-77.22$ & 58.25 \\
\hline $\mathbf{4}$ & Estimated number of leaves & 2718.95 & $1687.66-3634.33$ & 16.83 \\
\hline $\mathbf{5}$ & $\begin{array}{l}\text { Fresh weight of 100 leaves } \\
\text { (g) }\end{array}$ & 64.57 & $48.16-87.00$ & 64.57 \\
\hline $\mathbf{6}$ & Dry weight of 100 leaves $(\mathrm{g})$ & 33.71 & $25.16-50.33$ & 33.71 \\
\hline $\mathbf{7}$ & Leaf dry matter content $(\%)$ & 48.19 & $41.22-55.56$ & 48.19 \\
\hline $\mathbf{8}$ & Fodder yield (kg) & 11.10 & $8.84-13.81$ & 13.29 \\
\hline $\mathbf{9}$ & Total fresh green leaf & 1770.81 & $893.36-3024.97$ & 12.97 \\
\hline & biomass $(\mathrm{g})$ & & & \\
\hline
\end{tabular}

Table.5 General mean, range, standard deviation (S.D.) and coefficient of variance (C.V.) of Proximate fodder analysis among different families of Grewia optiva

\begin{tabular}{|c|c|c|c|c|}
\hline Sr. No. & Parameter & Mean & Range & C.V. \\
\hline $\mathbf{1}$ & Crude protein (\%) & 20.74 & $18.09-22.11$ & 1.36 \\
\hline $\mathbf{2}$ & Crude fibre (\%) & 20.52 & $18.58-21.83$ & 1.74 \\
\hline $\mathbf{3}$ & Ether extract (\%) & 5.34 & $4.65-5.88$ & 3.22 \\
\hline $\mathbf{4}$ & Total ash (\%) & 11.97 & $10.74-13.13$ & 2.05 \\
\hline $\mathbf{5}$ & NFE (\%) & 41.18 & $38.37-44-25$ & 1.19 \\
\hline
\end{tabular}

On the basis of mean performance, it is concluded that half sib families SI-15, SO-3, HA-2, HA-3, HA-4, SO-7, SH-7, SO-4, SI-6 and SI-14 excelled well for most of the morphometric and fodder quality traits. These half sib families can further be used in the breeding programme. The higher amount of variation among the different families can be used to improve the quality of livestock, through better quality and more fodder to check their alarming pressure on forest wealth of Western Himalayas, especially during the lean winter season.

\section{References}

Bhat, G.S. 1999. Provenance variation in seed and seedling traits of Albizia lebbek Benth. M.Sc. Thesis. Dr Y.S. Parmar University of Horticulture and Forestry, Nauni-Solan (H.P.) 88 p.

Bhagta, S. 2015. Progeny evaluation of open pollinated seedling seed orchard of Grewia optiva Drummond. Department of Tree Improvement and Genetic Resources, Dr. Yashwant Singh Parmar University of Horticulture and forestry, Nauni. 
p. 108 .

Bhat, S Saleem. 2010, Evaluation of established open pollinated Seedling seed orchard of Grewia optiva Drummond. Department of Tree Improvement and Genetic Resources, Dr. Yashwant Singh Parmar University of Horiculture and forestry, Nauni. p.89.

Choudhary, P. 2000. Studies on genetic variation in open-pollinated families of Toona ciliata. M.Sc. Thesis. Dr. Y.S. Parmar University of Horticulture and Forestry, Nauni, Solan $73 \mathrm{p}$

Coleman, 1982. Chromosome numbers of angiosperms collected in the state of Sao Paulo. Brazilian Journal of Genetics , 5(3): 533-549.

Gera, M, Gera N, Aggarwal R and Gpta B N. 2002. Genetic variation in biochemical contents in foliage of twenty seed sources of Dalbergia sissoo. Ind. For. 128(7):726-737.

Hooker, JD. 1875. Flora of British India L. Revve \& Co., London.

Pant, K S, Prabhakar M and Panwar P. 2003. Floral biology of Grewia optiva Drummond. Annals of Plant and Soil Research 5(10): 61-69.

Kaushal, P S. 1978. Screening of beul trees (Grewia optiva) for superior nutritative stains Msc. Thesis H.P.U.64

Rathore, Amandeep. 1997. Evaluation of selected genotypes of Grewia optiva. M.Sc.Thesis Dr. Y.S. Parmar University of Horticulture and Forestry, Nauni-Solan (H.P.) 55 p.

Singh, R. 2005. Survey of socio-economic profile of farmers and animal feed resources in the mountains of Himachal Pradesh. Himalayan Ecology 13(2): 12-15.

Singh, R and Bimal M. 2004. Traditional animal rearing practices in mountains of Himachal Pradesh. ENVIS Bulletin 12(1): Himalayan Ecology

Sehgal, R N and Jaswal S. 1996. Seed source variation on Grewia optiva. In: Proc. QFRI-IUFRO conference on tree improvement for sustainable tropical Forestry Caloundra, Australia 27 October to November 1996

Sankhyan, H P, Bawa R and Mariappan N. 2009. Fodder quality evaluation of Grewia laevigata Vahl: a lesser known tree species of Shiwaliks. Ind. For. 135(3): 347-360.

H.P. Sankhyan and Shikha Bhagta, 2016, fodder quality analysis of open pollinated seedling seed orchard of Grewia Optiva Drumond, The Bioscan 11(2):709-713.

Wani, A M, Raj A J and Chauhan.2009. Association analysis for morphological and biomass traits in Bauhinia variegata seedlings. Ind. J. Trop. Biodiv. 16(1): 61-70.

\section{How to cite this article:}

Shikha Bhagta, H.P. Sankhyan, J.P. Sharma and Reena Kumari. 2019. Assessment of Variability in Half Sib Progenies of Grewia optiva Drummond for Various Qualitative and Quantitative Traits in North Western Himalayas. Int.J.Curr.Microbiol.App.Sci. 8(04): 16611669. doi: https://doi.org/10.20546/ijcmas.2019.804.194 